\title{
Pollution of Ekulu River in Enugu: A Case of Negative Human Impact on the Environment
}

\author{
${ }^{1}$ Ezenwaji E. E., ${ }^{2}$ Eduputa, B. M. and ${ }^{3}$ Uwadiegwu, B. O. \\ ${ }^{I}$ Department of Geography and MeteorologyNnamdiAzikiwe University, Awka, Nigeria \\ ${ }^{2,3}$ Department of Environmental ManagementNnamdiAzikiwe University, Awka,Nigeria
}

\begin{abstract}
River water pollution is very common in most urban rivers in Nigeria. The obvious reason is that many human activities take place especially within their immediate watershed. The Ekulu river basin is wholly located within the built up areas of Enugu and the result is that a range of human and economic activities produce contaminants that daily pollute the river as the river serve as a receptacle for the discharge of these waste effluents. The aim of this paper is to identify those human activities and land uses that tend to produce wastes and the extent of pollution of the river by these contaminants using physico-chemical and microbiological parameters. Data for the study was generated from the water samples collected from six sections of the river; these include a point before the river enters the urban area, while four other sample points were within the urban area and the last is at a point outside the urban area. Two analytical techniques were employed in the study and they area; Kruskal Wallis test and Post Hoc test. The result shows that the samples from various sites are statistically different while the degree of pollution was highest in the built up areas. Implications of the pollution on urban development was discussed while recommendations were made on how the problem will be contained.
\end{abstract}

Keywords: Rivers, pollution, samples, techniques, urban.

\section{Introduction}

River water pollution is very common in most urban rivers in Nigeria. The obvious reason for this could be traced to a plethora of human activities taking place within their immediate watershed which use the river water as a ready receptacle of wastes. This is inspite of the fact that the river water is a rich resource to be protected at all costs. Water quality is indeed important in assessing the health of a watershed and could be used to make necessary management decisions to control current and future pollution of receiving water bodies (Khadam and Kaluarachchi 2006, Behbahaninia et al. 2009).

The physico-chemical and biological composition of surface water and its properties in a particular region is basically governed by natural processes and human activities which can either be point or non-point sources such as urbanization, industrial as well as agricultural activities. Human activities are a major factor determining the quality of surface water through atmospheric pollution, effluent discharges, use of agricultural chemicals and eroded soils. Also, urban land uses create impervious surfaces resulting in storm runoff events that negatively affect stream ecosystems and water quality. Sickman et al (2007), was of the view that rivers in urban watersheds with substantial urban land use experience increased inputs and varying compositions of organic matter. Also, in urban areas large quantities of natural and synthetic estrogens, other pharmaceutical by products and disease causing bacteria are entering rivers and streams through the release of wastewater from sewage treatment plants and effluents from septic tanks (Kinzelman et al 2003, Williams et al 2003, Gross et al, 2004, Pejman, 2009 and Ezenwaji 2010).

In Nigeria, numerous studies on physico -chemical and biological pollution of urban rivers have been carried out (Butu 2011, 2013, Olofin 1991, Ezedike 1982, Nwachukwu 1998, Efobi 2001, Ubani 2009, Nweke 2013, Nwaichi et al 2013, Chimelu 2014)and in Enugu; Chukwu 1995, Ezenwaji 2010). Furthermore, Udeze (1988) and very few others have particularly studied the pollution level of Ekulu river. However, out of these authors, only Udeze (1988) did tangentially discussed the effects of urban land use on the degradation of Ekulu river water,but the study was done over 25 years now and needs to be updated. The study is therefore, aimed at identifying the human activities and land uses as well as their associated pollutants that result in Ekulu river water pollution and the extent of that pollution on the river.

\section{Area of Study}

\section{Materials And Methods}

Ekulu river lies in the northern part of Enugu urban area and flows eastwards throughout its entire course and its main tributaries comprise Iva and Obuga streams (Fig.1). 


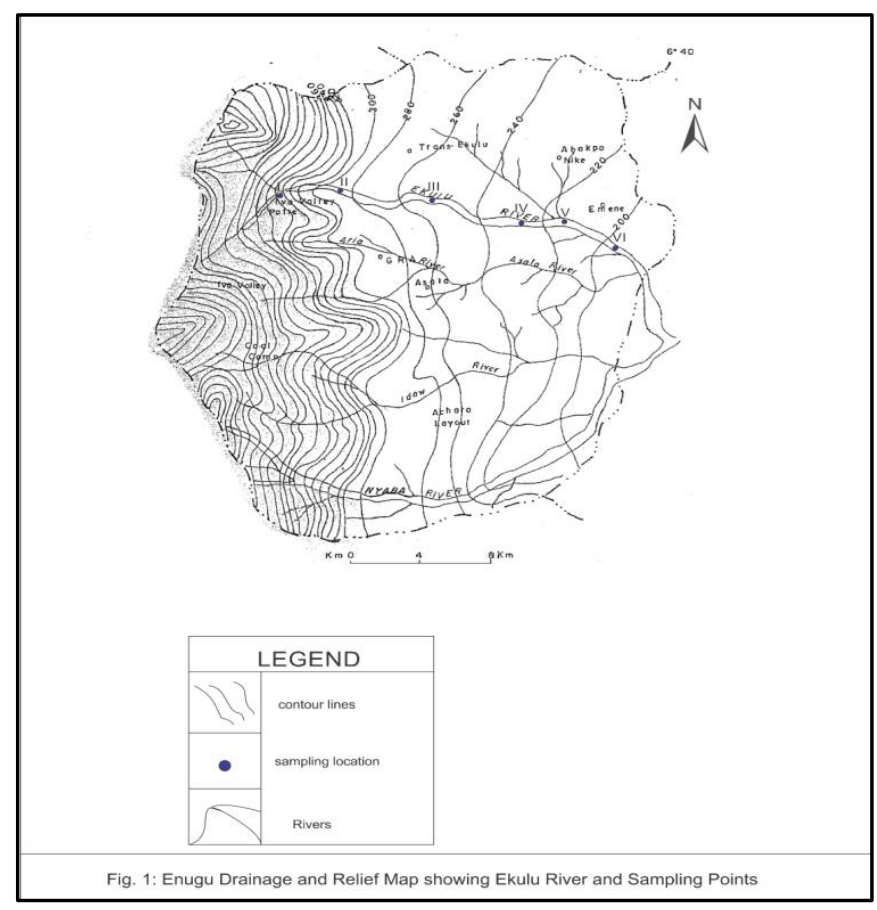

According to Udeze (1988) as the Ekulu flows through the northern parts of the city, it passes through various urban land uses as well as Emene Industrial area where major industries in Enugu are located. It rises from the escapement located west of the city where its head waters continuously erode the southern parts of the escapement backwards and it passes through a wide valley which separates the rest of Enugu from Trans-Ekulu layout and Abakpa Nike district. From its source to its confluence with Nyabariver in the south, Ekulu river is about 30kilometers in length. It is a perennial river with high stage which is characterized by flooding of its wide valley during the rainy season and low stage with large deposits of sand at its valley during the dry season, showing varying quantities of water on its channel at different seasons of the year. The river is utilized in various sections of the city for industrial, domestic and recreational - fishing and swimming activities by residents. The Enugu State Water Corporation utilizes water from the river as one of the sources of intake for their water works at Ekulu.

The river flows through three geological formations namely the false bedded sandstone (Ajalli formation) at its source, west of the city, then the lower Coal measure (Mamu formation) and Enugu shale that constituted the largest formation in terms of area along the course of the river before it empties into Nyaba river south east of the city. Ajalli formation is a body of sandstone which is thick, friable and poorly sorted and is sometimes white in colour and often contains iron stains which signify ferroginization. In addition, it is characterized by extreme porosity which allows easy and free movement of water. On the other hand, the lower Coal measures are very thin bands of sedimentary rocks that stretch from southern Benue into Enugu urban area and are on the lower part of the false - bedded sandstone which are associated with the escarpment and contains marine intercalations (Orajiaka 1975). This formation is the treasure base of the town because it is here that some deposits of coal is found and mined. Furthermore, the Enugu shale which occupies the major part of the Enugu east are again bands of sedimentary rocks of campano - maestrichtian origin. It is typified by dark grey friable shale with occasional thin beds of sandstone and are shallow water origins and characterize by conditions that produce coal bearing beds. It has relatively rich soils which support agriculture in the area.

Although, coal mining, was abandoned some years back, it used to be the primary extractive industry on which Enugu is well known. The major area along the course of Ekulu River had coal activities, the relics of which together with some coal particles flowing in the river are still visible. Also, along the river banks are the lower income settlements (Iva Valley Pottery) at upper course of the river, then the Ugwu-Aborand Ugbo Odogwu squatter settlements downstream. Further, down the river at both its left and right banks are patrol stations, industries and some housing estates. About $6 \mathrm{kms}$ from the source of the river is the Abakpa Nike settlement at its West and Army Barracks by the East. Then, around Emene, variegated types of industries are located at its banks together with markets and patrol stations. Also, some farming activities go on almost in its entire wide valley. 


\section{Data Collection}

From the source of Ekulu riverto the point it finally leaves the built up area is $21 \mathrm{~km}$. Six points were designated as sampling locations along the river. The choice of the locations was determined by the type of dominant human activity taking place at each of the locations. These dominant activities are domestic, agricultural, mining, commercial and industrial. Be that as it may, the following locations were chosen for sampling.

\section{Sampling Location I}

This location is where about four small streams converge to form the river. The waters of these streams was mainly come down from the escarpment and the old mine tunnels.

\section{Sampling Location II}

This location is where the Iva Valley Pottery slum settlement has close contact with the river (Plate I). At this point, the inhabitants dump refuse near the river where they dispose some of their domestic wastes.

\section{Sampling Location III}

This location is below the bridge that leads into the new market in Enugu. Again, this is the location where the inhabitants of Ugwu-Abor collect their domestic water supply as well as a point where sand activities in the river and at it banks are most intense.

\section{Sampling Location IV}

This sampling location is about $200 \mathrm{~m}$ away from the bridge that leads to GRA Enugu. Here the prevalent activities are urban agriculture where a lot of vegetables and cassava are cultivated with a lot of artificial fertilizer.

\section{Sampling Location V}

This location is about 50m downstream from the Abakpa bridge. Here, there are a lot of petrol stations, as well as settlements such as some parts of Abakpa Nike and Army Barracks. There is a lot of human contact at this point as the inhabitants of the settlements fetch water at this location. Also, at above this point, about $100 \mathrm{~m}$ upstream, car washing activities take place on a 12 hour basis.

\section{Sampling Location VI}

This sampling location is located about 100m downstream from Oye Emene market and at the rear end of some chemical and pharmaceutical industries. Here there are a huge waste dump nears the river which are refuse collections from the market.

The water samples from these locations, with plastic bottles of about 0.5 litre volume and the analysis was carried out within 24 hours. The bottles were labeled accordingly from samples $1-6$.

\section{Method Of Data Analysis}

Two methods of data analyses were utilized in the study and they are the laboratory analysis to determine the concentration of our isolated 17 variables which were classified according to Ezemonye (2009) as follows -

i. $\quad$ Physical Characteristics - Temperature (T),Colour (C), Turbidity (TU) and Total Dissolved Solid (TDS).

ii. Chemical Characteristics - PH, Electoral Conductivity (EC), Dissolved Oxygen (DO), Biochemical Oxygen Demand (BOD) and Hardness (HA).

iii. Nutrients - Phosphates (P), Nitrates (N), Sulphate (S), Ammonia (A), Calcium (CA), Iron (I), and Sodium (NA).

iv. Biological Characteristics - Feacal Coliform Bacteria.

Temperature, $\mathrm{pH}$ and $\mathrm{DO}$ concentrations of the water were measured on site by a thermometer, $\mathrm{pH}$ and DO meter (using HACH sensION156 Portable) respectively (APHA, 1998), BOD was determined by the Winkler azide method. Turbidity by the nephelometric method (using 2100AN turbidimeter) (APHA, 1998). The membrane filter technique was used to determine the number of colony forming units per $100 \mathrm{ml}$ (cfu/100ml) of feacal coliforms in sampling water (APHA, 1998). Nitrate and phosphate by spectrophotometric. Total dissolved solids with a filter membrane apparatus in accordance with APHA 2540D protocol, dissolved oxygen by the Azide modification of Winkler's method adapted for the HACH DR 2010 equipment for standard methods. Total Hardness was determined using ETDA titrating procedure, calcium by tritimetric EDTA method.Sulphate turbidimetrically with UV/visible spectrophotometer at a wavelength of $425 \mathrm{~mm}$ in accordance with ASTM D4130, iron by phenathronic method, Ammonia by colorimetric nesslerization i.e. the use of nessler's regent which reacts with ammonia to form a yellow colour and the amount of colour developed is 
directly proportional to the amount of ammonia present. Sodium was analyzed by flame photometry. Colour was determined by mere observation. The results of the laboratory test of each of the parameters are presented in Table 1.

Table 1: Mean values of the physico-chemical and biological parameters of Ekulu River in various sampling locations

\begin{tabular}{|c|c|c|c|c|c|c|c|}
\hline \multirow[t]{2}{*}{ Parameter } & \multicolumn{7}{|c|}{ Sample Locations } \\
\hline & I & II & III & IV & $\mathbf{V}$ & VI & $\begin{array}{l}\text { WHO } \\
\text { (standard } \\
\text { 2007) }\end{array}$ \\
\hline Temperature & 23.61 & 24.12 & 24.58 & 24.61 & 24.60 & 24.61 & 25 \\
\hline $\mathrm{pH}$ & 5.11 & 4.94 & 4.93 & 4.94 & 4.88 & 5.93 & 6.5 \\
\hline Turbidity & 62.0 & 92.0 & 102.0 & 101.0 & 124.0 & 72.0 & 25 \\
\hline TDS & 94.20 & 120.60 & 126.50 & 118.70 & 133.20 & 128.40 & 100 \\
\hline $\begin{array}{l}\text { Electrical } \\
\text { Conductivity }\end{array}$ & 1120 & 1114 & 1118 & 1119 & 1134 & 1133 & 1000 \\
\hline Dissolved Oxygen & 14.00 & 13.63 & 15.04 & 13.22 & 13.68 & 13.10 & 4 \\
\hline BOD & 1.58 & 1.63 & 1.62 & 1.63 & 1.63 & 1.63 & 0.1 \\
\hline Phosphate & 0.19 & 0.88 & 0.92 & 0.20 & 0.41 & 0.40 & 10 \\
\hline Sodium & 5.92 & 6.26 & 6.84 & 6.91 & 6.90 & 6.93 & 6.27 \\
\hline Iron & 0.2 & 0.1 & 0.1 & 0.1 & 0.1 & 0.1 & 1.14 \\
\hline Ammonia & 1.40 & 1.33 & 1.28 & 1.30 & 1.41 & 1.38 & - \\
\hline Calcium & 9.20 & 8.44 & 8.12 & 8.05 & 8.13 & 8.20 & 2.00 \\
\hline Nitrate & 9.33 & 9.28 & 9.48 & 9.40 & 9.39 & 9.42 & 10 \\
\hline Chloride & 20 & 22 & 22 & 22 & 22 & 22 & 600 \\
\hline Hardness & 0.33 & 0.28 & 0.30 & 0.32 & 0.33 & 0.33 & 0.45 \\
\hline Colour & Cloudy & Cloudy & Muddy & Muddy & Muddy & Muddy & Clear \\
\hline $\begin{array}{ll}\text { Feacal } & \text { Coliform } \\
\text { Bacteria } & \\
\end{array}$ & 22.4 & 29.6 & 38.6 & 32.4 & 31.6 & 23.2 & $1 \mathrm{cfu} / \mathrm{E}-\mathrm{coli}$ \\
\hline
\end{tabular}

\section{Statistical Analysis}

Two statistical techniques were employed in the study and they are, Kruskal Wallis and Post Hoc test. Kruskal Wallis test was employed to ascertain the measure of the degree to which individual locations differ from one another in terms of river water quality. The general formula for the technique is written as:

$$
\begin{aligned}
& \mathrm{H}=\frac{12}{\mathrm{~N}(\mathrm{~N}+1) \quad \mathrm{nj}} \text { Rj2- } 3(\mathrm{~N}-1) \\
& \text { Where } \\
& \mathrm{nj}=\text { the number of observations in the jth group } \\
& \mathrm{Rj}=\text { the sum of the rank in the jth group } \\
& \mathrm{N}=\sum \mathrm{nj}=\text { total sample size. }
\end{aligned}
$$

Post Hoc test is concerned with finding relationships between sub groups of sampled populations. This test compares each sample with WHO standard, while the significance value now tells us how one sample group is related to the other and the result is achieved through a multiple comparison box. It is generally designed for situations in which the researcher wants to ascertain the differences among the means of the groups so as to provide specific information on which means are significantly different from the other.

\section{Results And Discussion}

The result of the Kruskal Wallis test statistics is presented in Table 2

Table 2: Kruskal Wallis Result.

\begin{tabular}{|l|l|l|l|l|}
\hline Factors & N & Median & Ave Rank & Z \\
\hline 0.01 & 1 & 3.000 & 35.5 & 0.00 \\
\hline 0.01 & 1 & 2.000 & 6.5 & 1.28 \\
\hline 0.01 & 1 & 1.000 & 7.5 & -1.39 \\
\hline 0.05 & 1 & 2.000 & 21.5 & -0.69 \\
\hline 0.10 & 1 & 5.000 & 63.5 & 1.39 \\
\hline 0.31 & 1 & 4.000 & 49.5 & 0.69 \\
\hline 0.42 & 1 & 3.000 & 35.5 & 0.00 \\
\hline 0.54 & 1 & 2.000 & 21.5 & -0.69 \\
\hline 0.58 & 3.000 & 33.5 & 0.00 \\
\hline 0.62 & 1 & 1.000 & 7.5 & -1.39 \\
\hline 0.64 & 1 & 2.000 & 21.5 & -0.69 \\
\hline 0.67 & 1 & 4.000 & 49.5 & 0.69 \\
\hline 1.00 & 1 & 4.000 & 49.5 & 0.69 \\
\hline 1.01 & 1 & 2.000 & 21.5 & -0.69 \\
\hline
\end{tabular}


Pollution of Ekulu River in Enugu: A Case of Negative Human Impact on the Environment

\begin{tabular}{|c|c|c|c|c|}
\hline 1.20 & 1 & 3.000 & 35.5 & 0.00 \\
\hline 1.30 & 1 & 4.000 & 49.5 & 0.69 \\
\hline 1.32 & 1 & 1.000 & 7.5 & -1.39 \\
\hline 1.33 & 1 & 3.000 & 35.5 & 0.00 \\
\hline 1.37 & 1 & 1.000 & 7.5 & 1.39 \\
\hline 1.44 & 1 & 3.000 & 35.5 & 0.00 \\
\hline 1.67 & 1 & 2.000 & 21.5 & -0.69 \\
\hline 1.71 & 1 & 2.000 & 21.5 & 0.69 \\
\hline 1.78 & 1 & 1.000 & 7.5 & 1.39 \\
\hline 1.83 & 1 & 3.000 & 43.2 & 0.00 \\
\hline 1.90 & 1 & 2.000 & 21.5 & 0.69 \\
\hline 1.96 & 1 & 4.000 & 21.5 & 0.69 \\
\hline 1.98 & 1 & 1.000 & 7.5 & -1.39 \\
\hline 2.00 & 1 & 4.000 & 49.5 & 0.69 \\
\hline 2.01 & 1 & 3.000 & 35.5 & 0.00 \\
\hline 2.16 & 1 & 2.000 & 21.5 & -0.69 \\
\hline 2.20 & 1 & 3.000 & 7.5 & 0.00 \\
\hline 2.24 & 1 & 1.000 & 63.5 & 1.39 \\
\hline 2.30 & 1 & 1.000 & 7.5 & -1.39 \\
\hline 2.40 . & 1 & 3.000 & 7.5 & 0.000 \\
\hline 3.54 & 1 & 2.000 & 35.5 & 0.00 \\
\hline 4.00 & 1 & 5.000 & 63.5 & 1.39 \\
\hline 4.44 & 1 & 3.000 & 49.5 & 0.69 \\
\hline 5.00 & 1 & 5.000 & 63.5 & 1.39 \\
\hline 5.33 & 1 & 1.000 & 7.5 & -1.39 \\
\hline 5.50 & 1 & 2.000 & 35.5 & 0.00 \\
\hline 5.70 & 1 & 2.000 & 21.5 & 0.00 \\
\hline 5.80 & 1 & 1.000 & 63.5 & 1.39 \\
\hline 5.90 & 1 & 4.000 & 49.5 & 0.69 \\
\hline 6.05 & 1 & 2.000 & 21.5 & -0.69 \\
\hline 6.15 & 1 & 1.000 & 7.5 & -1.39 \\
\hline 6.21 & 1 & 2.000 & 21.5 & -0.69 \\
\hline 6.25 & 1 & 3.000 & 35.5 & 0.00 \\
\hline 6.30 & 1 & 1.000 & 7.5 & -1.39 \\
\hline 6.33 & 1 & 1.000 & 7.5 & 0.39 \\
\hline 6.50 & 2 & 3.500 & 42.5 & 0.49 \\
\hline 6.90 & 1 & 3.000 & 35.5 & 0.00 \\
\hline 7.20 & 1 & 4.000 & 49.5 & 0.69 \\
\hline 7.41 & 1 & 2.000 & 21.5 & 1.39 \\
\hline 7.61 & 1 & 3.000 & 35.5 & 0.00 \\
\hline 7.80 & 1 & 1.000 & 7.5 & -0.69 \\
\hline 7.99 & 1 & 4.000 & 49.5 & 0.69 \\
\hline 8.12 & 1 & 3.000 & 35.5 & 0.00 \\
\hline 8.15 & 1 & 2.000 & 21.5 & -0.69 \\
\hline 8.18 & 1 & 1.000 & 7.5 & -1.39 \\
\hline 8.31 & 1 & 2.000 & 21.5 & 1.39 \\
\hline 9.10 & 1 & 4.000 & 49.5 & 0.69 \\
\hline 9.28 & 1 & 5.000 & 63.5 & 2.44 \\
\hline 9.74 & 1 & 3.000 & 35.5 & 0.00 \\
\hline 9.88 & 1 & 2.000 & 21.5 & -0.69 \\
\hline 10.00 & 3 & 5.000 & 63.5 & 2.44 \\
\hline 10.90 & 1 & 4.000 & 49.5 & 0.69 \\
\hline 12.40 & 1 & 2.000 & 21.5 & -0.69 \\
\hline 12.48 & 1 & 1.000 & 7.5 & -1.39 \\
\hline 13.90 & 1 & 1.000 & 7.5 & -1.39 \\
\hline 14.00 & 1 & 4.000 & 49.5 & 0.69 \\
\hline 14.02 & 1 & 3.000 & 35.5 & 0.00 \\
\hline 14.70 & 1 & 2.000 & 21.5 & -0.69 \\
\hline 14.80 & 1 & 4.000 & 49.5 & 0.69 \\
\hline 15.50 & 1 & 3.000 & 35.5 & 0.00 \\
\hline 16.00 & 1 & 2.000 & 21.5 & -0.69 \\
\hline 16.17 & 1 & 2.000 & 21.5 & -0.69 \\
\hline 16.30 & 1 & 4.000 & 49.5 & 0.69 \\
\hline 16.54 & 1 & 4.000 & 49.5 & 0.69 \\
\hline 16.70 & 1 & 1.000 & 7.5 & -1.39 \\
\hline 17.20 & 1 & 3.000 & 35.5 & 0.00 \\
\hline 17.49 & 1 & 5.000 & 63.5 & 1.39 \\
\hline 18.63 & 1 & 1.000 & 7.5 & -1.39 \\
\hline 20.00 & 1 & 5.000 & 63.5 & 1.39 \\
\hline 22.00 & 1 & 4.000 & 49.5 & 0.69 \\
\hline
\end{tabular}


Pollution of Ekulu River in Enugu: A Case of Negative Human Impact on the Environment

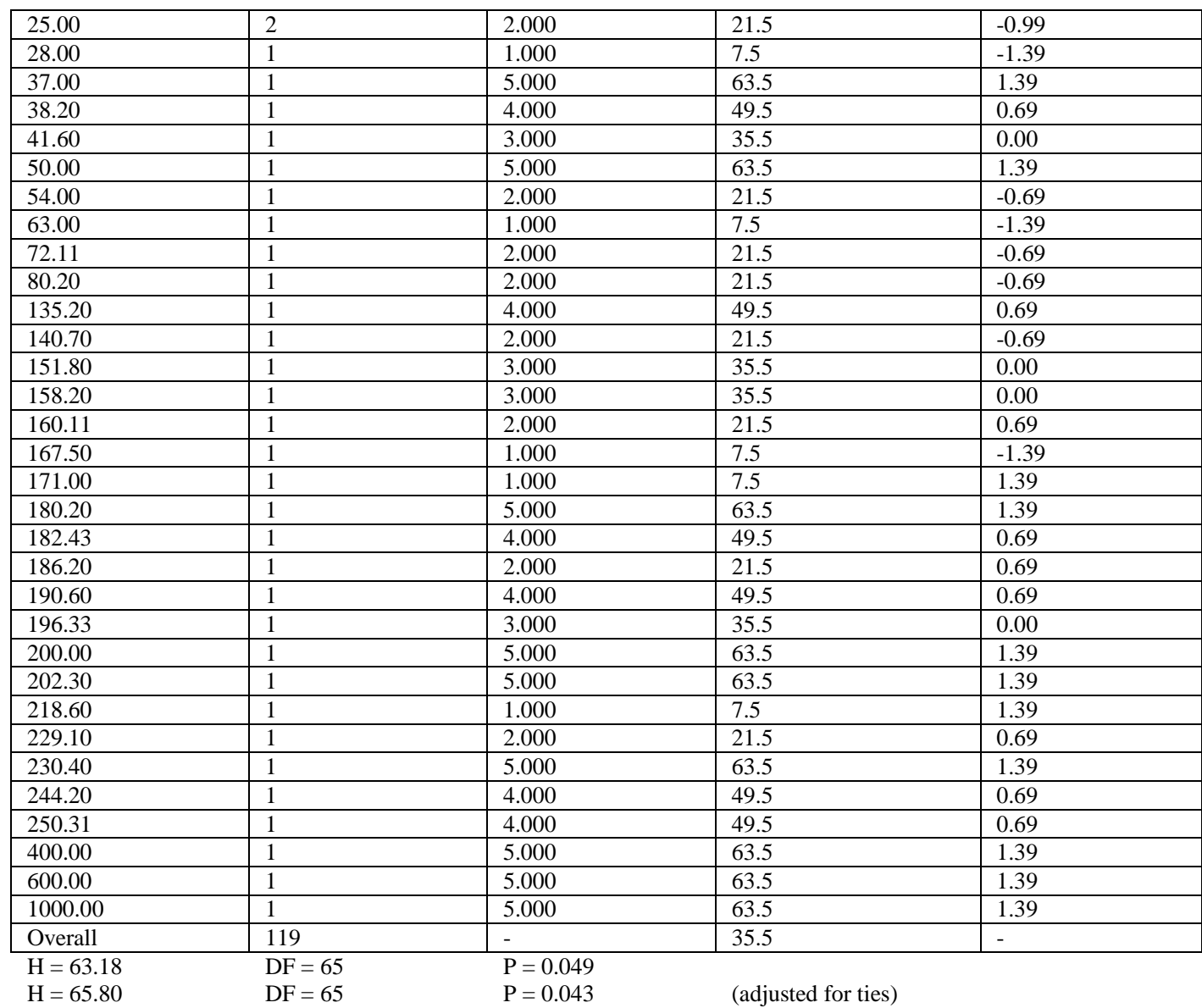

From the table 2, it could be seen that the p-value of the test is 0.043 which is less than the package critical of 0.05 and this implies that there exists enough evidence to conclude that the water quality at each of the six locations as well as the WHO control is significantly different from each other. Next we ran the Post Hoc test to determine the land use near the river which has contributed most to the pollution of the river water. This can be assessed by comparing the mean water quality in each location with that of WHO (the control) and calculating their level of significance which when it is less than 0.05 is taken as statistically significant.

The sampling locations and their dominant land uses are summarized in Table 3.

Table 3: Sampling Locations and Dominant Land uses associated with them.

\begin{tabular}{|c|l|}
\hline Sampling Location & Dominant Land use \\
\hline I & Coal Mining \\
\hline II & Residential \\
\hline III & Residential and Sand Mining \\
\hline IV & Agricultural \\
\hline V & Residential and Car Washing \\
\hline VI & Industrial and Commercial \\
\hline
\end{tabular}

From Table 1,we could see that the value of the physico-chemical and biological parameters were examined and out of 17 of these parameters, 9 of them were above the maximum permissible level set by WHO. Those above the WHO level are pH, Turbidity, Conductivity, Dissolved Oxygen, Biochemical Oxygen Demand, Phosphates, Sodium, Calcium, Colour and Feacal Coliform Bacteria.

The physical parameters that are above the permissible level are: colour which is muddy suggesting contamination with dissolved parent materials. Also, turbidity above the permissible level indicates the presence of large number of tiny colloidal particles which can provide a hiding place for pathogenic organisms. This, therefore, requires that water from the river need to be treated before consumption. Total Dissolved solids range from $94 \mathrm{mg} / \mathrm{l}$ at the sampling location 1 to as high as $133.20 \mathrm{mg} / \mathrm{l}$ at the sampling location V. Generally, the values obtained from all locations except one is above the WHO permissible level. Total Dissolved Solidis a measure of the amount of particulate solids in solution. A measure of TDS is an indicator of non-point source pollution problems associated with various land use practices (Sridhar, 2002, Imoisi et al, 2012). TDS in all 
locations is above the maximum permissible level byWHO and this could be due to a codification of water by elevated microbial degradation of organic debris and concentrated dissolved solids.

The chemical parameters that were above the WHO permissible levels are $\mathrm{pH}$, Electrical Conductivity (EC), Dissolved Oxygen (DO), and Biochemical Oxygen Demand (BOD).

The PH of the water samples ranges from 4.88 to 5.93. This is a clear indication that the water has strong acidic content. The water cannot therefore be considered for consumption due to its acidic nature. The main source of acid in the water is the Onyeama mine - the abandoned mines. Electrical conductivity is high in all the locations and always serves as an indication of poor quality water. Impurities present in water are charged with ions which conduct currents. At times it depends on the quality of dissolved salt present in the sample or a consequence of high evapotranspiration in the area making the amounts of dissolved ions to increase.

Again, Dissolved Oxygen (DO) is high in all the sampled locations. This may be due to copious growth of phytoplankton with less water flow, disturbance and uprooting leading to increased generation of $\mathrm{O}_{2}$ by photosynthesis activities. It was, however, observed that certain reaches of the river have less water flow which might result in high DO. According to Imoisi et al (2012) DO could be caused by decomposing organic matter, dissolved gases, industrial wastes, mineral wastes and landfill leachate.

Biochemical Oxygen Demand BOD of the water is slightly higher than WHO 2007 limit. This is an indication of significant bacteriological action on the river. On the nutrients content of the river, the following were above the WHO 2007 permissible level; sodium and calcium. The reason for high sodium content in water may be as a result of the fact that sodium chloride constitutes the bulk of amount of wastes deposited in the river by households. Calcium concentration in water.

The total coliform bacteria concentration is higher than the WHO 2007 recommended maximum. The presence of feacal coliforms or E-Coli has widely been used as an indicator for the presence of any of the waterborne pathogens. WHO recommends that no feacal coliform be present in $100 \mathrm{ml}$ of drinking water. From the result obtained from the water samples, it could be seen that Ekulu River is seriously feacally polluted. The concentration of coliform bacteria was observed in all the sampling locations which coincides with the reaches more accessible to people who either defecate along the banks, inside the water channel or washing and bathing at those locations. Generally, the source of coliform bacteria includes human wastes, urban land runoff and domestic sewage.

To further validate the result obtained by the application of Kruskal Wallis and compare the sample results at the six locations with WHO 2007 (control) standard, Post Hoc test was applied. The multiple comparison box obtained from this test is shown in Table 4

Table 4: Multiple Comparison Test of the Water Quality in each Sample Location and WHO Standard.

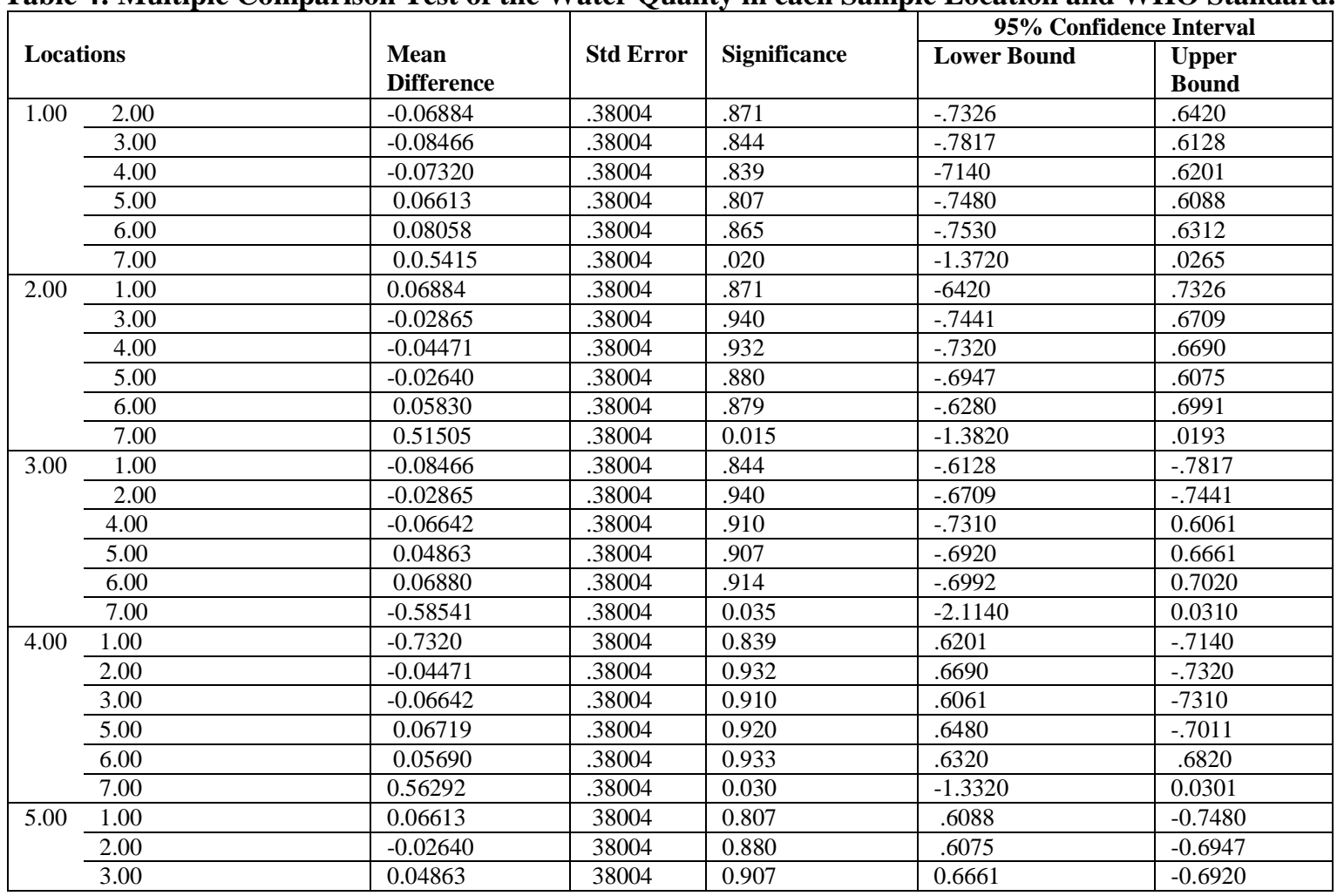


Pollution of Ekulu River in Enugu: A Case of Negative Human Impact on the Environment

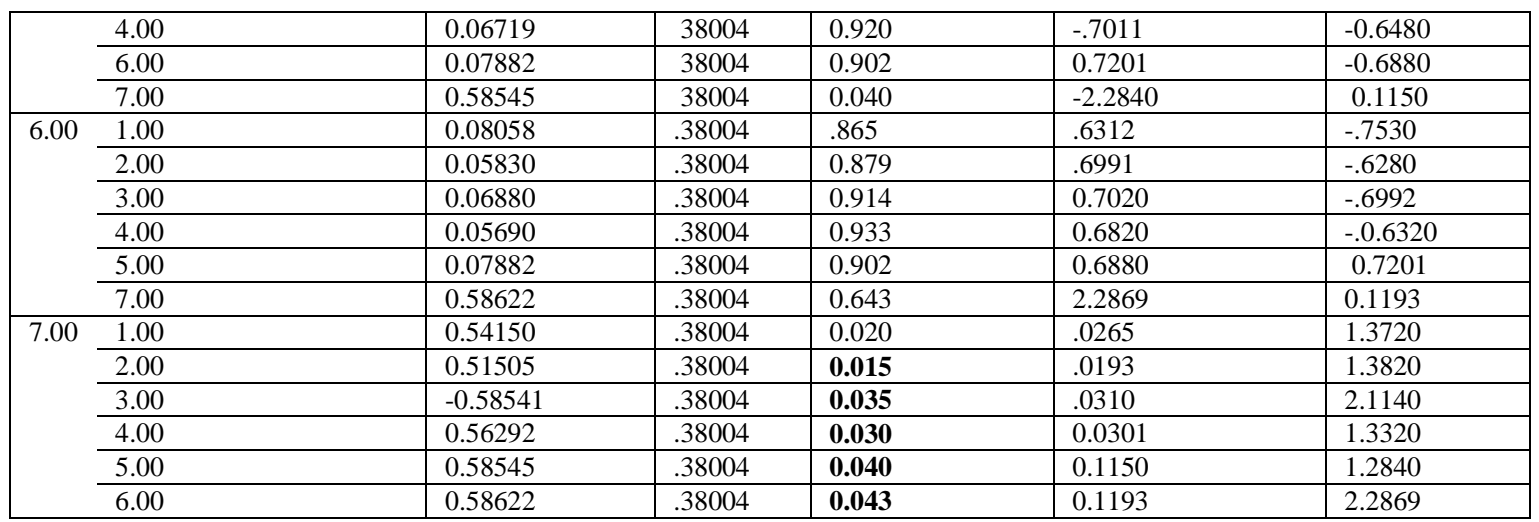

In the interpretation of Post Hoc result,if the p-value is more than 0.05, it indicates that the value of the means of samples are statistically different, while when it is below 0.05 it indicates that a difference occur. From Table 4 it could be seen for example that in the first box, the relationship between location 1 and 2 is $0.871,1$ and $3(0.844), 1$ and $4(0.839) 1$ and $5(0.807), 1$ and $6(0.865)$. What all these clearly show is that the difference between the results of the samples achieved at all the six locations are nearly the same, showing that the entire stretch of the urban river water is polluted. The result achieved from the locations contract sharply with that obtained between them and 7 which is WHO. This clearly shows that the result obtained in those locations is significantly different from the WHO standard. This conclusion is better revealed when the entire comparison of the locationsand WHO is presented.(Table 5)

Table 5: Comparison between WHO and the 6 Locations

\begin{tabular}{|l|l|}
\hline Comparison & Significance \\
\hline Between 7 and 1 & 0.020 \\
\hline Between 7 and 2 & 0.015 \\
\hline Between 7 and 3 & 0.035 \\
\hline Between 7 and 4 & 0.030 \\
\hline Between 7 and 5 & 0.040 \\
\hline Between 7 and 6 & 0.043 \\
\hline
\end{tabular}

From Table 5 it could be seen that the most polluted location is location 2 with 0.015 significance which is dominate by residential land use. From the result of the sample collected at this location, the main pollution is microbiological and what this means in essence is that massive defecation is taking place at the banks of the area at this location as well as inside the river itself. This observation is corroborated from our investigation at nearby Ugwu-Abor, a squatter settlement where very few households have any form of toilet, forcing over $90 \%$ of the inhabitants to practice open defecation which is either washed into the river or directly done inside the water channel. The next polluted area is found in location 1 with a p-value of 0.020 . Careful investigation revealed that this area has low $\mathrm{pH}$ level which is indicative of acid content in water. Here the main source of acid waters are the Onyeama and other abandoned mines that litter that location. Abandoned mines were found to be releasing acidic water which finds their way into Ekulu River. The strong acidic water at this location is diluted downstream with water brought by tributary streams. Location 4 with the p-value of 0.030 is the third most polluted location.This location is dominated by agricultural land use where artificial fertilizer is prodigiously employed in the cultivation of vegetables and cassava. The major pollutant of the river in this location is phosphate which are derived from the soil drainage. In modern agricultural practices, fertilizers containing nitrates and phosphates are added to the soil and some of these are washed-off through the rainfall, irrigation and drainage into the water bodies where they highly disturb the aquatic ecosystem. The injection of these chemical substances into the river disrupt the nitrogen and phosphorous balance in water thereby negatively affecting plant growth. Indiscriminate and excessive use of fertilizer on land has created an adverse ecological effect on aquatic ecosystem because some of them are washed into the river from the farm nearby through seepage and drainage. One of the major ingredients of fertilizer is phosphate salts which cause algae boom, asa lot of algae growth was observed in this location. The three remaining locations are polluted in this order; location $3(0.035)$ is the fourth, location $5(0.040)$ the fifth and location $6(0.043)$ the sixth. It could be explained that location six is least polluted because at that reach a lot of tributary channels have entered the river to dilute its heavy pollution observed at its upstream section.

\section{Implications of River Water Pollution on Urban Development}

Enugu is one of the oldest towns in Eastern Nigeria and such serious urbanization has taken place over the years. This, therefore, means that many urban services including water supply have failed to meet the 
demand of the ever growing population. The result is the growth of many squatter settlements as a response to the inability of urban government to provide housing for the ever increasing population inflow from the rural areas. Furthermore, both industrial and commercial activities have increased in number and complexities just as the residential. In the same manner, public institutions have sprung up in various parts of the town and all these make demands on the city's limited municipal water supply. The overstretched water demand that resulted was the major reason why residents opted to search and consume water from anywhere including acid mine water from Ekulu river. Again, some industries have elected to use the water channel as a waste dump for all kinds of industrial wastes. Commercial establishments found in almost all parts of the city dispose most of their wastes inside the water channels. This development has given rise to the pollution of water bodies found in the urban areas. Some obvious implications of this include.

i. Affliction of the inhabitants by different kinds of water borne, water washed and water based diseases. However, water borne diseases are the most manifest. Records obtained from hospital sources in TransEkulu, Abakpa and Emene districts of Enugu clearly show the following frightening situation; $90 \%$ of hospital visits by residents of Ugwu-Abor, Ugbo Odogwu and Agu Owa, all, squatter settlements in 2013 were as a result of water borne diseases, while over $80 \%$ of the inhabitants of Abakpa that visit the hospitals in 2013 were diagnosed of typhoid fever.

ii. The debilitating action of these diseases makes it difficult for the active population to embark on economic activities that will improve the economy of households in particular and urban area in general. This leads to the greater poverty of the people and by extension the poor economic development of the urban area.

iii. River water pollution also limits the aquatic life such as fish, crabs etc that are the rich protein source of the people. The limitations imposed by this on the protein consumption of the people further limit the food available on them and hence the escalation of hunger which is a barrier to meaningful urban development.

iv. Polluted water especially those that are acidic corrode the automobile body when used to wash cars and could subsequently lead to the destruction of such cars.

v. Ample and at times clean water supply is one of the necessary factors for the establishment of industries. The assumed availability of water supply is one reason why many industrialists want to establish industries in the urban areas. Industries such as soft drinks, all kinds of pharmaceuticals, bottled water and a range of other industries with high demand for sanitary water will not establish in the urban area if water supply quality is found to be a limiting factor. This then will translate to poor industrial development of the urban area.

\section{Recommendations}

To limit the river water pollution on Ekulu River the following recommendations are made.

i. Those who use the water from the river for drinking, cooking and domestic hygienic uses should endeavour to locally treat it by boiling and filtering before use.

ii. Ekulu River has its highest pollution location in Agu-Abor. This then means that the Enugu State Government will begin to think about embarking in urban renewal programme of the settlement with a view to constructing low cost modern houses with toilet facilities for the inhabitants. This will undoubtedly limit open defecation in the watershed.

iii. Farming activities near the river must be such that will not be done with artificial fertilizer. Those who want to engage in farming in the area must be meant to sign an undertaken not to use artificial fertilizer.

iv. The abandoned coalmines that release water to the Ekulu river should be blocked so that water that runs from them to pollute the river will be stopped.

v. Government will ensure that no part of the river or its watershed will be used either by residents or industries to dump wastes.

vi. Serious human activities should no longer be allowed near the river. On this relevant authorities will create enough corridors devoid of economic activities so as to reduce the river water pollution.

vii. Industries located close to the river to ensure that wastes are treated before releasing them into the river water.

\section{Conclusion}

The need to continuously study the quality of water from rivers that pass through urban areas cannot be over laboured because of the importance of such rivers to the health and general development of the urban areas. The repeated analysis and study of Ekulu river water by researches is encouraged as the result of these research constantly produce the status of the river water quality at any point in time. In Enugu urban area of Nigeria, Ekulu river has been the source of drinking water, urban agriculture and indeed sand mining. These activities as important as they are, produce and inject contaminants into the river that pollute its water. The pollution of Ekulu river in Enugu by these substances was established in this study as a veritable case of negative human impact on the environment. The study first revealed the degree of pollution of the waters of this river by each of 
these physico-chemical and biological substances and their spatial disposition as revealed by Kruskal Wallis result. The mean in each of the results of the 6 locations were compared with WHO 2007 standard to ascertain their conformity to the desired standard but the result of Post - Hoc statistical test clearly revealed that all locations are sharply deviated from this standard with location 2 showing the highest level of departure while location 6, the least. The land use in each of the locations together with the type of pollutant were discussed and it was found that each land use produce a particular contaminant that lower the river water quality. The implications of this environmental problem to the development of Enugu urban area were also highlighted and recommendations on how the problem will be contained by putting measure that would ensure that users of water from the river water especially for drinking and other hygienic purposes boil and filter it before use. The need for the government to embark on urban renewal programme of the slum and squatter settlements by providing toilets for their inhabitants that would limit open defecation at the banks and inside the water channel are among other recommendations which were outlined.

\section{References}

[1]. APHA, (1998).Standard Methods for the Examination of Water and Wastewater. American Public Health Association, $18^{\text {th }}$ Edition, Washington DC, USA.

[2]. Behbahaninia, A., Mirbagheri, S.A., Khorasani, Nouri J., Javid A.N. (2009): "Heavy Metal Contamination of Municipal Effluent in Soil and Plants". J. Food Agri Environ,7(3-4) $851-856$.

[3]. Butu, A. W.(2011)."Sources and Levels of Metal Contaminants in River Kubanni, Zaria Nigeria. Unpublished Ph.D Thesis, Department of Geography ABU Zaria, Nigeria".

[4]. Butu, A. W. (2013). Concentration of Metal Pollutants in River Kubanni, Zaria, Nigeria. Journal of Natural Sciences Research 3(2) $19-25$.

[5]. Chimelu, I. C. (2014).River Water Pollution in Awka Urban Area, Nigeria. (A Case Study of Obibia River). An unpublished B.Sc. Project Department of Geography and Meteorology, Nnamdi Azikiwe University, Awka.

[6]. Chukwu, K. (1995).The Influence of Urbanized Catchment Area on Storm Water Disposal. A study of Enugu Urban Area. Unpublished M.Sc. Thesis, University of Nigeria, Nsukka.

[7]. Efobi, E. (2001).A Study of River Water Pollution at the Nkissi River in Onitsha District of Anambra State.UnpublishedM.Sc. Thesis University of Nigeria, Nsukka.

[8]. Ezedike, A.N. (1982).River Water Pollution in Owerri Nigeria. Unpublished B.Sc Project, Department of Geography, University of Nigeria, Nsukka.

[9]. Ezemonye, (2009).Surface and Groundwater Quality of Enugu Urban Area. An Unpublished PhD Thesis Department of Geography University of Nigeria, Nsukka.

[10]. Ezenwaji, E. and Orji, M. (2010)."Seasonal Fludiations of Microbiological Contaminants entering an Urban Watershed. The case of Asata River in Enugu, Nigeria". Tropical Built Environment Journal 1(1) 1 - 10.

[11]. Garizi, A.Z. and Sadoddin, A. (2011)."Assessment of Seasonal Variations of Chemical Characteristics in Surface Water using Multivariate Statistical Methods". Int. J. Environmental Science Tech 8(3) 581 - 592.

[12]. Ibe J.E. (2014)."Effects of Domestic Waster in Idaw River, Enugu Urban Nigeria”. Urbanization and Water Supply, 3(4) 212 220.

[13]. Imoisi, O. B., Ayesanmi, A. F., and Uwumarongid - Ilori, E.G. (2012).“Assessment of Groundwater Quality in a typical Urban Settlement of Resident close to three dumpsites in South-South, Nigeria". Journal of Environmental Science and Water Resources 1(1) Pp $12-17$.

[14]. Khadam, I.M. and Kaluarachchi, J.J. (2006)."Water quality modelling under hydrologic variability and parameter uncertainty using erosion - scaled export coefficient”.J. Hydrol. 330 (1-2) $354-367$.

[15]. Kinzelman, J. Ng, C; Jackson E, Gradus S, Bagley, R. (2003).“Enterococci as indicators of Lake Michigan recreational water quality. Comparison of two Methodologies and their Impacts on Public Health Regulatory Events". Applied Environmental Microbiology69(i), $92-96$.

[16]. Niemi, G.J., Devore P., Deterbeck, N., Tylor, D., Lima, A. (1990). “Overview of Case Studies on Recovery of Aquatic Systems from Disturbances". Environmental Management, 14(5) 571 - 587.

[17]. Nwaichi, E. O., Monanu, M.O. and Njoku, C.O. (2013)."Water Quality Assessment of RU MuoDomaya Stream: Chemical and Biological Status". Research Journal of Engineering and Applied Science (2(1) 29 - 34.

[18]. Nwachukwu, B., Okereke, A. and Ukpai, L. O. (1998). The Pollution Level of Ofamiri River, Owerri.Environmental Review, 2 (i) 6 -15 .

[19]. Nweke, P. (2013). Effects of Urbanization on Rivers Nworie and Otamiri in Owerri, Nigeria. Unpublished B.Sc. Project Nnamdi Azikiwe University, Awka.

[20]. Olofin, E.A. (1991)."Surface Water Pollution: A menace to the quality of life in urban area". Paper Presented at the $34^{\text {th }}$ Annual Conference of the Nigerian Geographical Association (NGA) Owerri.

[21]. Orajiaka, S. O. (1975). “Geology" in Ofomata GEK (ed.) Nigeria in Maps:Eastern States Ethiopia Publishing Home, Benin City.

[22]. Reinhard, M. (2004)."Occurrence and Fate of Pharmaceuticals and Alkyphenol Ethoxylade Metabolites in an Effluent Dominated River and Wetland”.Environ Texicol Chemical, 23(9) $2074-2083$.

[23]. Sickman, J. O., Zanoli, M. J., and Mann, H. L. (2007). "Effects of Urbanization on Organic Carbon Loads in the Sacraments River California". Water Resource 43, W11422 1-15.

[24]. Sridhar, MKC (2002). A Guide to Environmental Health in Tchobanoglous G, Schrieder, ED (1985), Addison - Wesley Reading.

[25]. Ubani, B.C. (2009)."Chemical Pollutants in Nkissi Rain Water in Onitsha Urban Area, Nigeria”. Journal of Urban Development $3(2) 28-34$.

[26]. Udeze, M. (1988).River Water Pollution in Enugu Urban Area. Unpublished M.Sc. Thesis, University of Nigeria, Nsukka.

[27]. Ufia, I.D., Ekpo, F. E. and Etim, D. E. (2013).“Influence of Heavy Metals Pollution in Borehole Water Collected within Abandoned Battery Industry, Essien Udim, Nigeria". Journal of Environmental Science and Water Resources 2(1) Pp 022 - 026.

[28]. Williams, R.J., Johnson, A.C., Smith, J.J. L., Kanda, R. (2003)."Steroid Estrogen Profiles along stretches arising from sewage treatment works discharges". Environmental Science Tech., 37(9) $1744-1750$. 